
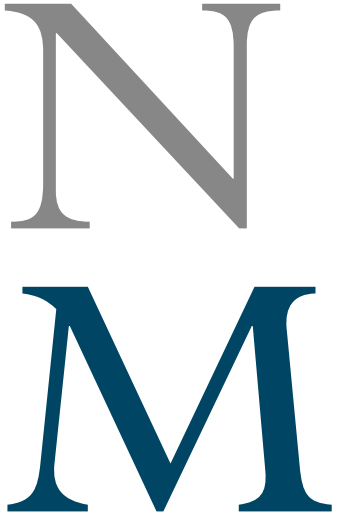
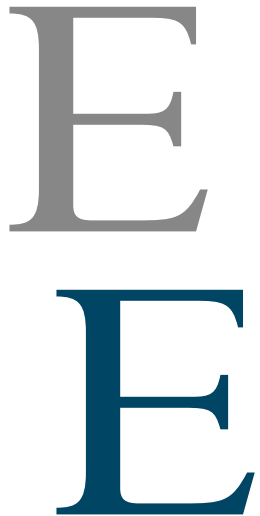
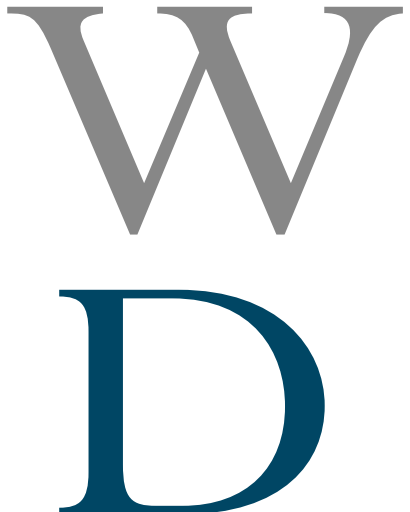
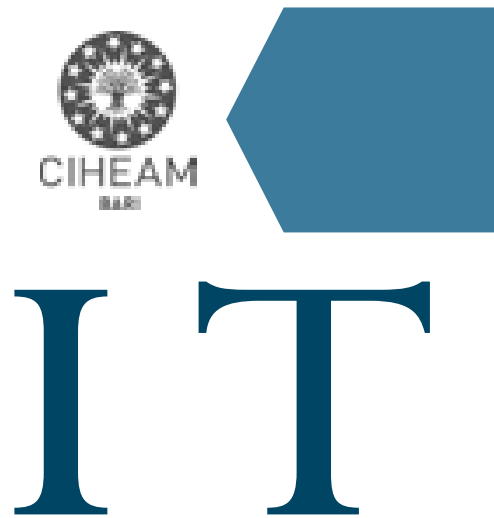

MEDITERRANEAN JOURNAL OF ECONOMICS, AGRICULTURE AND ENVIRONMENT

Poste Italiane Spa Spedizione in Abbonamento Postale Periodico ROC Centro Nord aut. $\mathrm{N}^{\circ} 0029-€ 15,00$.

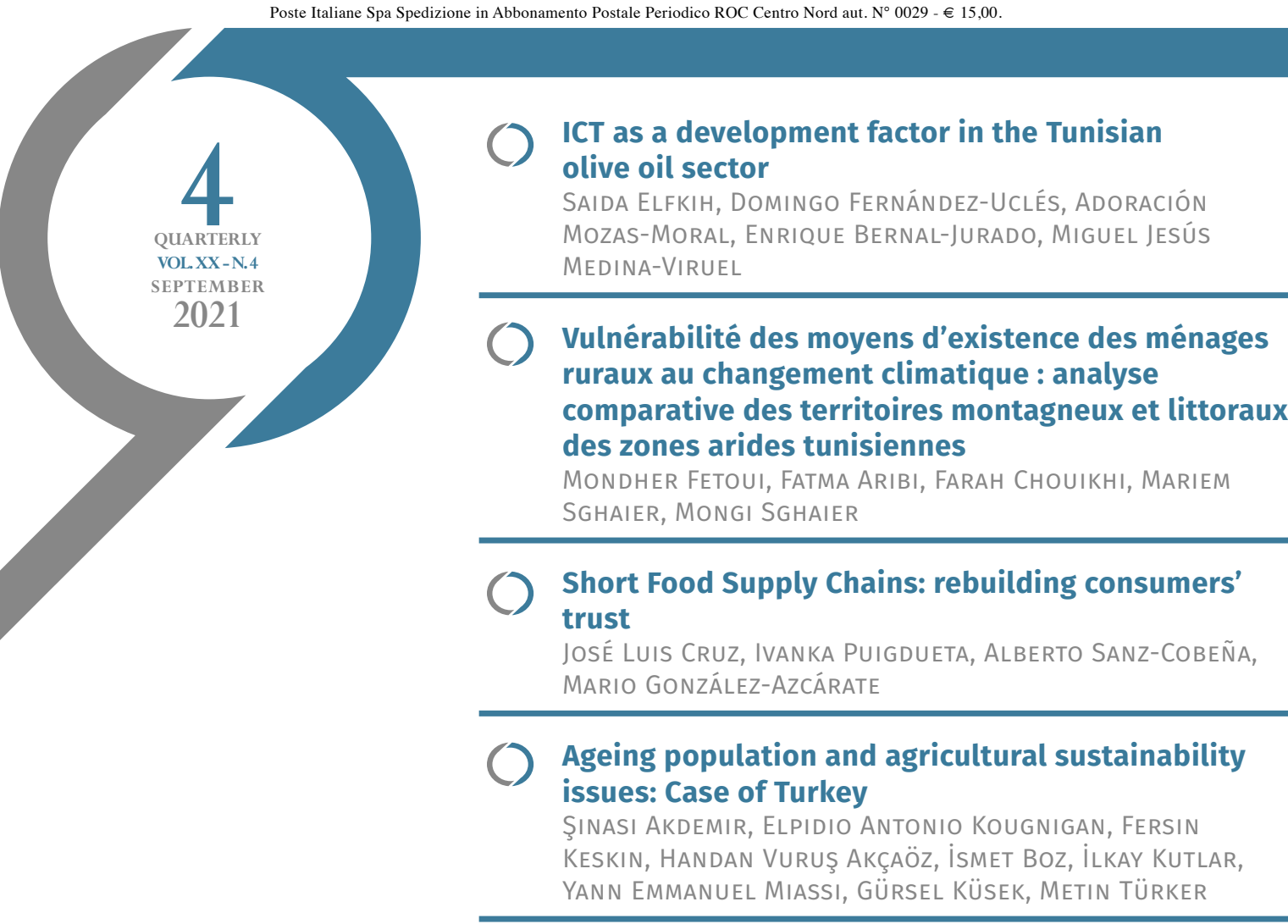




\title{
Ageing population and agricultural sustainability issues: Case of Turkey
}

\author{
Şinasi AKdemir*, Elpidio Antonio Kougnigan*, Fersin Keskin**,

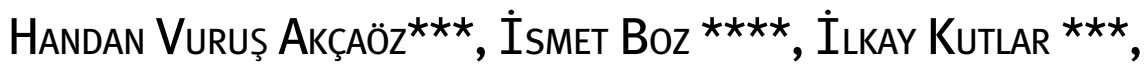 \\ Yann Emmanuel Miassı*, Gürsel KüSek**, Metin Türker ${ }^{\star \star}$
}

DOI: $10.30682 / \mathrm{nm} 2104 \mathrm{~d}$

JEL codes: J43, Q01, Q12

\begin{abstract}
Agriculture is a sector that is widely known to be impacted not only by the natural conditions of a country but also by other economic and political sectors. Turkish agriculture, in a context marked in recent years by a rural exodus of young people, marks the vagueness of the current state of the agricultural sector and its future. It is with this in mind that this research was carried out, based on a questionnaire survey of 312 producers in 5 provinces of Turkey, to assess the impact of the ageing of the rural population on the agricultural sector. The results of this study show that with age, producers invest less in agricultural activity, altogether abandoning productions requiring more labour. The possibility of taking over the family farm by descendants plays an important role in the degree of involvement of producers. Through these findings, this study makes it possible to address targeted agricultural policies according to age stages.
\end{abstract}

Keywords: Aging farming population, Farm succession, Impact, Farming sustainability, Turkey.

\section{Introduction}

Living in rural areas brings with it spatial disadvantages in reaching basic living standards for elderly people. The inability of the elderly to participate in the migration process and their "being behind" change the age structure of the rural area and brings along problems in accessing services. While a significant portion of the elderly population lives in rural areas, they cannot have regular access to basic public services due to the physical and social infrastructure deficiencies in rural areas. During the migration process, the migration of relatives of the elderly to urban ar- eas does not only affect the service consumption of the elderly residents but also causes the decrease and weakening of social and support networks. Old age is not a period that is expressed only in chronological terms of the number of years lived. This period is a period that includes individual differences, social conditions of the period, and environmental conditions. Rural old age reflects an old age that is shaped according to the conditions of the place of residence. Studies on rural areas draw a graphic that decreases in number especially with the phenomenon of urbanization. However, the change in social

\footnotetext{
* Department of Agricultural Economics, Faculty of Agriculture, University of Çukurova, Adana, Turkey.

** Ministry of Agriculture and Livestock, Ankara, Turkey.

*** Department of Agricultural Economics, Akdeniz University, Antalya, Turkey.

**** Department of Agricultural Economics, Ondokuz Mayıs University, Turkey.

Corresponding author: akdemir@cu.edu.tr
} 
structure, especially with the phenomenon of immigration, caused the rural area to be associated with the elderly. This situation raises the necessity to analyze the rural area in terms of old age. Rural life is a disadvantageous place in many aspects such as education, transportation, and health. Besides, the ageing process becomes more difficult with the emergence of conditions such as illness, disability, and need for care. A problematic area emerges when both the impossibilities of rural life and the negativities of old age combine (Acici, 2019).

Turkey is facing an accelerated ageing population phenomenon in rural areas. While the percentage of the population of 65 years old or above is at $9.1 \%$ on average in the country, rural areas count $13.4 \%$ of them (TurkStat, 2020). The sectoral distribution of the employed elderly population was examined with the household labour force survey (TurkStat, 2020). According to the results, $64.7 \%$ of the elderly population older than 65 work in agriculture, $28.1 \%$ in services, $5.3 \%$ in industry, $1.9 \%$ in construction. It is good that the agriculture sector provides several jobs for them, on the other hand; some precautions should be taken to have younger people work in the sector for the sustainability of agricultural activities. In France for instance, since 1975, the age structure of the active agricultural population in rural areas makes farm exploitations turn to the familial workforce (Reboul, 1980). The author explains the diminution of the active population by the disappearance of farms. Factors such as longevity and rural exodus are the ones driving the changes (Akdemir and Miassi, 2019). This major demographic trend implies a possible transition in the farming scheme in the way of exit or disinvestment. The findings of Griffin et al. (2019) about "retirement age farmers' exit and disinvestment from farming" in the USA show that demographic factors such as gender, race, and age have statistically significant impacts on farmers' decisions to exit or to disinvest. Population structure in rural areas is a very important factor both for agricultural growth and for uncovering non-agricultural potential in rural areas. The modernization of agriculture, the spread of the use of new technologies, the growth of scales, the realization of new initiatives in rural areas seem more possible with a young, qualified, and entrepreneurial population. On the other hand, the solution of structural problems in agriculture is possible with a young population that ensures its future from agriculture and the rural economy. The EU has understood the importance of this issue and has been giving priority and weight to agricultural policies to promote the participation of youth in rural development (Shucksmith, 2010). Today, the use of the technologies of the fourth industrial revolution in agriculture is rapidly becoming widespread. Industry 4.0, which includes the Internet of Things (IoT), cloud technology, drones, sensors, and big data analytics, significantly reduces production costs and increases productivity and profitability in the agricultural sector. The expansion of the fourth industrial revolution in the agricultural sector in Turkey is holding back by one of the biggest structural problems to ensure food security, the ageing of the population living in rural areas. The migration of the active population living in rural areas for reasons such as work and education constitutes one of the main reasons for this demographic trend. According to 2017 migration statistics, approximately $50 \%$ of the 2.7 million internal migration population is between $15-30$ years old (TurkStat, 2019).

Among the biggest structural problems of Turkish agriculture, the small size of farms, the fragmented and scattered nature of agricultural land, which, moreover, is subject to joint ownership, come first. In other words, 6 ha of land per enterprise consists of 10 parcels belonging to 13 shareholders. These lands are cultivated by one of the shareholders living in the village. The number of parcels of land can be reduced by land consolidation, but the shareholding problem could not be solved, as land-banking applications could not be implemented. This situation prevents taking efficiency-increasing measures such as access to land and drilling wells on multi-share lands, improvement, and fruit growing. This structure causes productivity and income losses in limited land assets, increases costs, and weakens the competitiveness of enterprises. 
Another crucial problem in rural areas is that formerly cultivated land is left unused due to the ageing of the farming population and the migration of young people to the cities. In particular, the migration of young people living in disadvantaged regions where the soil, topography, and climatic conditions are insufficient for sustainable agriculture, and the elderly population contenting themselves with less land, leads to leaving previously cultivated land empty. According to a study conducted in 2018-2019, for reasons such as the elderly population, the rural exodus, including excessive fragmentation, questions of inheritance and succession, security issues, it emerges that in Turkey on 24 million hectares of agricultural land, about 2 million hectares $(8.2 \%)$ are unused, with $25 \%$ of those lands having irrigation possibilities (TOB, 2019). Efforts are underway to implement land banks, particularly leasing and co-production models, to bring empty land into production.

Studies on rural exodus in Turkey are many (Avsar, 1995; Coskun and Zaman, 2012; Altin, 2014) and various analyzing the economic and social impacts (Ekmekciler, 2011), its links with socioeconomic characteristics (Gurbuz and Karabulut, 2008), the gender aspect by focusing on women conditions during the transition, or even the threats it represents for the rural development (Tasgin, 2009). Akdemir (1994) and Yalcin and Kara (2016) oriented their studies onto rural exodus and its impacts on agricultural production; furthermore (Kuçuk, 2018) analyzed the ageing population and social politics' application in the world and Turkey. Despite the abundance of literature about important rural questions, studies about the ageing population from the farming perspective in Turkey are rare. Though the presence of an active population in rural areas is the guarantee of food security and sustainable agriculture. In the context where environmental and ecological conditions' degradation associated with climate changes constitute a serious threat to food supply (Eswaran et al., 1997) for a growing population, understand the implication of ageing in agriculture in Turkey - that is ranked among the least efficient countries of OECD in terms of ecological sustainability of its agriculture (Mollavelioglu et al., 2010) - is driven by the need to understand farmers' decisions factors, their involvement in agricultural activities and hence the impact on the sustainability of agriculture in Turkey. This study aims to reveal the socio-economic characteristics of the elderly population and to determine the relationship between ageing and agricultural sustainability.

\section{Methodology}

To shed light on the consequences of ageing on agriculture in rural areas, our study opted for a cross-sectional study that was carried out through a field survey. The questionnaire tool was used for this purpose during a field survey carried out in September 2019 in 5 provinces (Kars, Erzurum, Sivas, Corum, and Bolu) with 312 producers aged at least 40 years with purposive sampling, which is commonly used in qualitative research for the selection and collection of information (Palinkas et al., 2015).

The fact that the provinces where the surveys were conducted are also the provinces with many idle lands and the rural exodus continues, has special importance in terms of researching the sustainability of the elderly population and agriculture in these regions. In this study, farmers needed to be easily accessible, have enough amount of willingness to participate, and the ability to communicate, and also the farmers were included in the study based on the research purposes namely their lifestyles and the sustainability of farms. Therefore, purposive sampling was used rather than a random sampling method (Etikan et al., 2016).

The diversity of the villages made it possible to ensure the representativeness of the different possible social classes. As the overall objective of the study is to determine whether ageing indeed poses a threat to agricultural activity in Turkey, variables that can indicate the level of activity, and socio-economic characteristics were collected. These data were processed using the statistical software SPSS 23 giving results of descriptive statistics, cross-tabulation analyses, comparison test, and Kruskal Wallis non-parametric statistical Tests to describe the general characteristics on the 
socio-demographic level of the participants. Then was established the links between the socio-demographic variables, the agricultural activity levels of the respondents, and how the sustainability issues are affected by age.

We verified whether the variations were statistically important in the pre-test results. Although the assumption of a normal distribution of observed variables was not justified, we used the non-parametric approach referred to as the Kruskal-Wallis test to check the statistical significance of discrepancies between farmers' groups in pre-test results (Wilcox, 2009). It makes it possible to test the $\mathrm{H}_{0}$ hypothesis that the independent $k$ samples $(k \geq 3)$ derive from the same distribution. The test criterion of the Kruskal-Wallis test is the statistics distributed asymptotically with k-1 degrees of freedom under the validity of the null hypothesis $\chi^{2}-1$ (Hettmansperger et al., 1998).

$$
H=\frac{12}{n(n+1)} \sum_{i=1}^{k} \frac{T_{i}^{2}}{n_{i}}-3(n+1)
$$

If $H \geq x_{\alpha}^{2}(k-1)$, where $x_{\alpha}^{2}(k-1)$ is the critical value of the $\chi^{2}$ - distribution of $\mathrm{k}$ - 1 degree of freedom, the tested hypothesis $\mathrm{H}_{0}$ is rejected at the significance stage $\alpha$. If the null hypothesis in favour of the alternative hypothesis $\mathrm{H}_{1}$ is dismissed, meaning that $\mathrm{k}$ independent samples $(\mathrm{k}$ $\geq 3$ ) come from the same distribution, a new question is posed as to which sample pairs vary significantly (Andel, 2003). To answer this question, the Duncan test, Tukey method, Scheffe method, or Neményi test can be used (Voss, 2010). In our case, the multiple comparisons of mean ranks for the Kruskal-Wallis test were performed using the Kruskal-Wallis test of multiple comparisons via Z-score in the SPSS program.

$$
Z=\frac{\left|\overline{R_{l}}-\bar{R}_{\jmath}\right|}{\sqrt{\frac{n(n+1)}{12}\left(\frac{1}{n_{i}}+\frac{1}{n_{j}}\right)}} ; Z \geq Z_{\alpha}
$$

\section{Results and discussion}

\subsection{Socioeconomic characteristics}

A total of $92.3 \%$ of the participants in our study are male with a modal age range of 56 to 65 years $(44.2 \%)$. With a literacy rate of $92 \%$, most of them $(46.5 \%)$ have a primary education level, are married (93.3\%), living mostly $(69.9 \%)$ in their village native. A large majority $(85.2 \%)$ live with their partner, and only $5.9 \%$ live alone. Living alone is often frowned upon and can even be the subject of mockery and gossip ${ }^{1}$. This explains the reason why producers, following the death of their wives, most often proceed to a second marriage at the cost of rather expensive dowries (agricultural land, other precious goods). The number of children per household is often 3 or more ( $82.4 \%$ of cases), of which $6.1 \%$ are from different mothers. Focusing on marital status, $7 \%$ got married more than once, the cause is mainly the death of their previous partner. Almost three-fourth $(73 \%)$ of study participants live with one, two, or more of their child (ren); for those with whom they do not live together, $94.1 \%$ say they are still in contact. Contacts are frequent daily when they live in the same village $(47.5 \%)$, regular for those who are in the same province $(21 \%)$, or on special occasions for those not living in the same provinces $(31.5 \%)$. When it comes to affinities towards their children, $50.8 \%$ of participants are more satisfied with their girls. The reasons are mainly the frequency of visits $(37 \%$ of participants), telephone conversations (18\%), and then financial support (8.3\%). 87.6\% own agricultural land, $79.9 \%$ of farmers who own it operate their land themselves, $9.67 \%$ derive income from it through rental. 59\% have a retirement allowance and $13.4 \%$ of respondents benefit from social assistance.

Cross tabulation analyses reveal age as a key differentiator between groups. This is the case

\footnotetext{
1 This testimony is certified by Akdemir, one of the authors, whose late father Göçer Akdemir has personally experienced it. Mr. Göçer has migrated from Van to Murat province; over there after the death of his first wife, he had to offer a house to his second wife for the family to accept the marriage. When his second wife passed away, he could marry at the condition to ensure his pension of retirement and lands to his third wife. This work is therefore dedicated to him.
} 
Table 1 - Education level sorted by age (\%).

\begin{tabular}{|l|c|c|c|c|c|c|c|}
\hline \multicolumn{2}{|c|}{} & Illiterate & Literate & $\begin{array}{c}\text { Primary school } \\
\text { graduate }\end{array}$ & $\begin{array}{c}\text { High school } \\
\text { graduate }\end{array}$ & $\begin{array}{c}\text { College/University } \\
\text { graduate }\end{array}$ & Total \\
\hline \multirow{3}{*}{ Age } & $40-55$ & 3.20 & 7.40 & 43.60 & 38.30 & 7.40 & 100.00 \\
\cline { 2 - 8 } & $56-65$ & 5.10 & 15.90 & 51.40 & 21.70 & 5.80 & 100.00 \\
\cline { 2 - 8 } & $>65$ & 18.80 & 23.80 & 41.30 & 15.00 & 1.30 & 100.00 \\
\hline Average & & 9.03 & 15.70 & 45.43 & 25.00 & 4.83 & 100.00 \\
\hline
\end{tabular}

Source: Survey results, 2019.

with the level of education where the proportion of those with a secondary level or above decreases with age as shown in Table 1. Likewise, with age the number of children living with them decreases, results corroborated by the rate of marriage of their children, which changes positively with the age of the respondents.

The division of property between children, by the farmers, while they are still alive, is rare $(9.2 \%)$. In the event of a division of property, relations with the children are always good (93.3\%), as is the satisfaction they feel from the management of property by them. When asked to know the appreciation of the other inhabitants of the village (city or province) in the face of decisions on whether or not to divide property between heirs, the farmers in our survey do not often face controversial reactions; less than $6 \%$ of those around them believe they have made bad choices.

In the enterprises examined, the socio-economic characteristics of the operators by age groups and their opinions on agricultural activities are given in Table 2. To determine whether there is a relationship between variables, crosstabs tabulation and chi-square contingency tests were performed.

\subsubsection{Producers' lifestyle}

Participants in our survey are generally able to carry out their activities without the need for ongoing assistance. For their intimate needs (using the toilet, bathing, eating, clothing), they almost do it on their own. However, the more the activity requires a certain amount of effort or travel (paying bills, banking procedures, travel, etc.), the more help they get; $70 \%$ of the time the help comes from their wives or someone else in the supply runs. The cross-tabulation analysis was performed to determine a group difference based on age if any. Even though older people use help more than younger people do, the difference is not significant enough.

When it comes to farm-related decisions, producers claim to make their own decisions in over $60 \%$ of cases. However, representing at least $30 \%$, the weight of the family and its participation in decisions is not negligible.

To get informed, farmers do not often use the press; $28 \%$ read it daily or weekly. The radio is used significantly more than the press $(35 \%$ daily or weekly); $26.6 \%$ use it for information on agriculture. However, television is a channel, which brings together almost all farmers; in fact, $93.3 \%$ follow it on a daily or weekly basis, with $67 \%$ following programs related to agriculture. The rate of internet use is not negligible, however. The internet is used by $39.2 \%$ of producers per day or per week; $30.3 \%$ use it regularly to learn about agriculture. Even though the television audience among farmers remains high, cross-tabulation analysis indicates a significant difference across age groups. The older the age, the less frequently farmers follow programs relating to agriculture via television channels.

\subsection{Sustainability of farms}

\subsubsection{Farm succession}

One of the concerns about the subject of this study is the question of the ageing of the rural population and thus, the question of the succession of agricultural activity by future generations. Almost half $(45.6 \%)$ of the farmers questioned do not think that their children will continue farming activities. The reasons are specified in Figure 1.

Figure 1 reveals that the risks level and economic conditions are considered by farmers 
Table 2 - Farmers' socio-economic characteristics and views on agricultural activities by age groups.

\begin{tabular}{|c|c|c|c|c|c|c|}
\hline \multirow[b]{2}{*}{ Variables } & \multirow[b]{2}{*}{ Specifications } & \multicolumn{3}{|c|}{ Age groups } & \multirow[b]{2}{*}{$P$-value } & \multirow{2}{*}{$\begin{array}{l}\text { Difference } \\
\text { among } \\
\text { groups }\end{array}$} \\
\hline & & $40-55$ & $56-65$ & $\begin{array}{c}\text { Above } \\
65\end{array}$ & & \\
\hline Education & $\begin{array}{l}\text { Primary school graduate or } \\
\text { less }\end{array}$ & 54.3 & 72.5 & 83.8 & 0.000 & $* * *$ \\
\hline \multirow{2}{*}{ Marital status } & Widow & 3.2 & 4.3 & 10.0 & 0.178 & \\
\hline & \begin{tabular}{|l|} 
Second wife \\
\end{tabular} & 5.3 & 7.2 & 5.0 & 0.612 & \\
\hline Health & With chronic illness & 16.5 & 18.5 & 37.7 & 0.002 & $* * *$ \\
\hline \multirow{2}{*}{ Additional income } & Pensionable & 27.2 & 64.5 & 86.3 & 0.000 & $* * *$ \\
\hline & No additional income & 36.0 & 18.3 & 6.7 & 0.000 & $* * *$ \\
\hline $\begin{array}{l}\text { Transfer of } \\
\text { ownership }\end{array}$ & Goods-sharing & 6.0 & 9.8 & 11.5 & 0.440 & \\
\hline \multirow{9}{*}{$\begin{array}{l}\text { Decision making } \\
\text { regarding } \\
\text { agricultural activity }\end{array}$} & Investment decisions & 72.2 & 66.7 & 58.4 & 0.001 & $* * *$ \\
\hline & Saving decisions & 68.2 & 59.7 & 58.7 & 0.005 & $* * *$ \\
\hline & Financial decisions & 69.0 & 60.4 & 59.2 & 0.005 & $* * *$ \\
\hline & Future decisions & 66.7 & 56.7 & 59.2 & 0.017 & $* * *$ \\
\hline & \begin{tabular}{|l|} 
Business decisions \\
\end{tabular} & 67.8 & 60.2 & 56.6 & 0.003 & $* * *$ \\
\hline & Marketing decisions & 73.3 & 60.2 & 60.5 & 0.010 & $* * *$ \\
\hline & $\begin{array}{l}\text { Decisions regarding the } \\
\text { production pattern }\end{array}$ & 70.1 & 64.7 & 63.2 & 0.010 & $* * *$ \\
\hline & Outside business decisions & 70.1 & 62.4 & 57.9 & 0.002 & $* * *$ \\
\hline & Production process decisions & 72.2 & 66.7 & 58.4 & 0.001 & $* * *$ \\
\hline Satisfaction & Satisfied with life & 51.2 & 53.0 & 49.3 & 0.874 & \\
\hline Use of technology & Internet users every day & 46.1 & 24.2 & 9.1 & 0.000 & $* * *$ \\
\hline $\begin{array}{l}\text { Leaving agricultural } \\
\text { land empty in the } \\
\text { village }\end{array}$ & $\begin{array}{l}\text { Those who answer: because } \\
\text { of old age }\end{array}$ & 16.0 & 9.4 & 23.7 & 0.197 & \\
\hline \multirow{6}{*}{$\begin{array}{l}\text { What would I want } \\
\text { to do if I was young } \\
\text { or my children } \\
\text { continued my job? }\end{array}$} & Growing my business & 89.0 & 93.9 & 94.9 & 0.257 & \\
\hline & To buy a machine. to renew & 86.4 & 93.1 & 90.0 & 0.251 & \\
\hline & Investing in livestock & 91.1 & 91.7 & 87.3 & 0.556 & \\
\hline & $\begin{array}{l}\text { Setting up an irrigation } \\
\text { system }\end{array}$ & 82.8 & 77.7 & 72.4 & 0.281 & \\
\hline & $\begin{array}{l}\text { Choosing a more profitable } \\
\text { production system }\end{array}$ & 88.6 & 95.4 & 89.6 & 0.137 & \\
\hline & Use credit & 57.6 & 49.6 & 51.3 & 0.503 & \\
\hline \multirow{6}{*}{$\begin{array}{l}\text { Agricultural } \\
\text { activities that cannot } \\
\text { be done recently due } \\
\text { to old age }\end{array}$} & $\begin{array}{l}\text { I did not receive a production } \\
\text { loan. }\end{array}$ & 34.5 & 33.9 & 48.6 & 0.085 & \\
\hline & I did not get a consumer loan. & 34.1 & 31.7 & 50.7 & 0.022 & \\
\hline & $\begin{array}{l}\text { I avoided labour-intensive } \\
\text { products such as vegetable, } \\
\text { fruit, and livestock activities. }\end{array}$ & 28.9 & 41.9 & 60.6 & 0.000 & $* * *$ \\
\hline & $\begin{array}{l}\text { I did not use agricultural tool } \\
\text { machines. }\end{array}$ & 20.0 & 33.6 & 40.3 & 0.021 & $* * *$ \\
\hline & I did not work in the field. & 23.8 & 26.4 & 39.7 & 0.061 & \\
\hline & Other & 18.6 & 28.8 & 33.3 & 0.332 & \\
\hline
\end{tabular}

$* * *=$ There is a significant difference among the groups

Source: Survey results, 2019 
Figure 1 - Motivations against farm succession (\%).

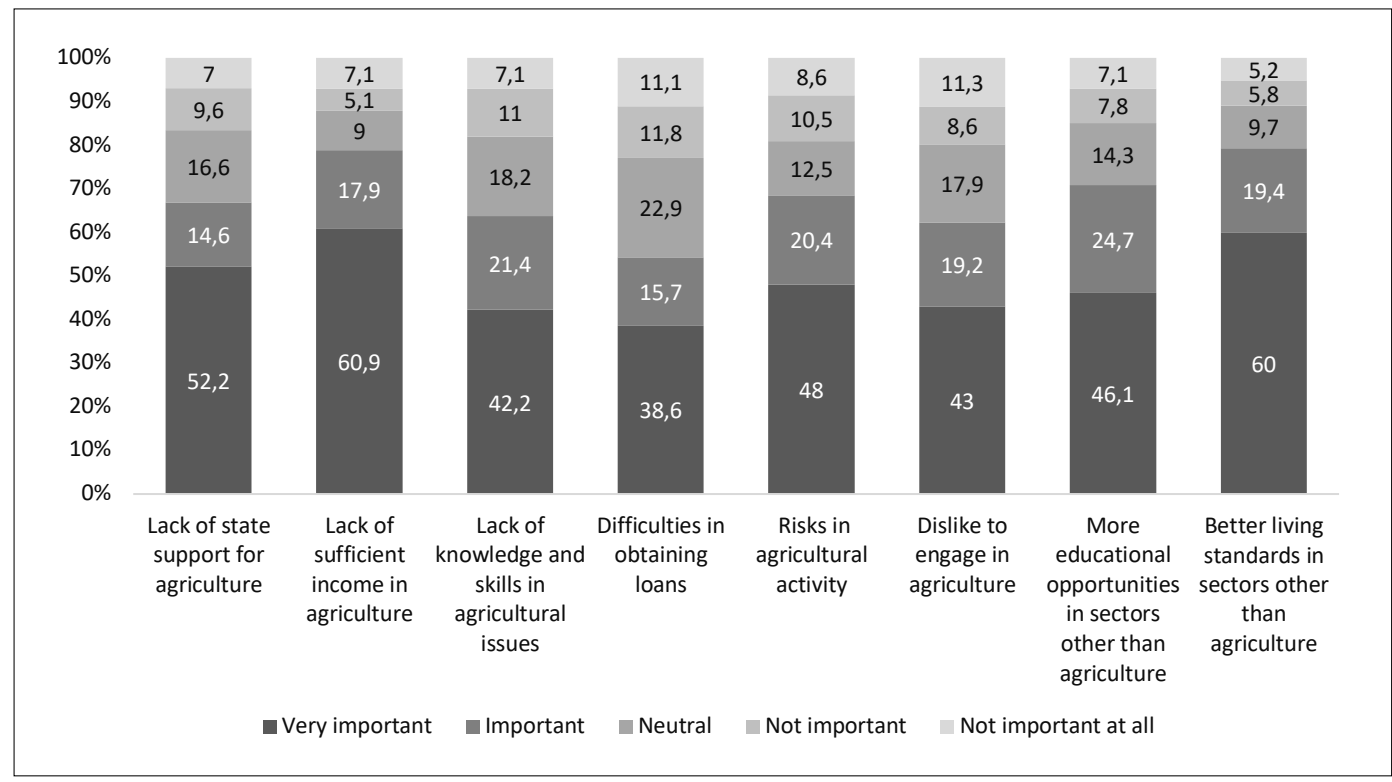

Source: Survey results, 2019.

to make the agricultural sector less and less attractive, added to that the fact that $62.2 \%$ of respondents think that their children are not at all interested in agricultural activities. As could be guessed, among the reasons mentioned by the participants in our study, the most notorious ones are the insufficiency of income generated by the activity $(78.8 \%$ of respondents answering no to succession), the better standards, and the living conditions in other sectors $(79.4 \%)$. Not insignificantly follow the outlets offered by branches of study other than agriculture $(70.2 \%)$, insufficient state support for the sector $(66.8 \%)$, and the risks of the activity itself (68.4\%).

In the study, 26 questions assigned scale points 5 (1. very important, 2. important, 3. neutral, 4. Not important, 5. it doesn't matter) were asked to determine the importance of elements that help farmers to continue agricultural activities in term of the sustainability issues in the agriculture sector. Since the points from answers are discrete type data, non-parametric Kruskal Wallis Tests were performed to understand an age effect on sustainability in agriculture.

Kruskal Wallis Test results are given in Table 3; the degree of freedom for all tests is 2 since the age variable has three groups. In the study, the per- centages of 40-55, 56-65, and above 65 years old farmers are 30.3, 44.23, and 25.64 respectively.

According to test results, the importance attached to making dissemination programs, conducting agricultural training programs for young people, having childcare (home economy) services, increasing credit opportunities, training on marketing, etc. is statistically different due to the ages of farmers ( $p$-values $<0.05$ ). Since the mean rank of younger farmers is less than that of the above 65 -year-old farmers, the factors mentioned above are more important for younger farmers to continue agricultural activities. For young farmers, it is obvious that educational supports and activities take great importance in terms of future working in agriculture. Also, credit opportunities should be increased and more accessible.

Experiences of farmers above the age of 65 would be important to understand precautions in staying in the agriculture sector for youngsters. Among the means of ranks belonging to old farmers, the means of ranks for guaranteed product prices (144.12) and providing additional job opportunities for family members (144.97) are less comparing other statements but not statistically different from other ages' ones. Even though, it could be said that they evaluated these 
Table 3 - Kruskal Wallis Test Results of elements for continuing agriculture production.

\begin{tabular}{|c|c|c|c|c|c|}
\hline \multirow{3}{*}{ Statement } & \multicolumn{3}{|c|}{ Age Groups } & \multirow{3}{*}{$\begin{array}{c}\text { Chi- } \\
\text { Square }\end{array}$} & \multirow{3}{*}{$P$-value } \\
\hline & \multirow{2}{*}{$\begin{array}{c}\text { 40-55 } \\
\text { Mean } \\
\text { Rank }\end{array}$} & \multirow{2}{*}{$\begin{array}{l}56-65 \\
\text { Mean } \\
\text { Rank } \\
\end{array}$} & \multirow{2}{*}{$\begin{array}{c}\text { Above } \\
65 \\
\text { Mean } \\
\text { Rank } \\
\end{array}$} & & \\
\hline & & & & & \\
\hline Making dissemination programs & 128.26 & 144.51 & 163.36 & 7.56 & 0.020 \\
\hline Not having too much debt & 141.62 & 138.08 & 161.04 & 4.35 & 0.110 \\
\hline Finding loan when needed & 144.57 & 139.95 & 156.39 & 2.06 & 0.358 \\
\hline Having non-agricultural income & 141.51 & 138.55 & 156.30 & 2.54 & 0.281 \\
\hline Agricultural support by State & 145.69 & 139.01 & 154.73 & 2.04 & 0.361 \\
\hline No difficulties in recruiting workers & 142.07 & 135.02 & 161.76 & 5.41 & 0.067 \\
\hline $\begin{array}{l}\text { Visit and assistance of agricultural engineers from } \\
\text { pesticide dealers }\end{array}$ & 135.43 & 140.81 & 161.64 & 4.70 & 0.096 \\
\hline $\begin{array}{l}\text { Visit and assistance of agricultural engineers from } \\
\text { agricultural organizations }\end{array}$ & 132.98 & 141.38 & 157.59 & 3.91 & 0.142 \\
\hline Family members working outside the firm & 131.56 & 145.08 & 156.72 & 3.90 & 0.142 \\
\hline $\begin{array}{l}\text { Conducting agricultural training programs for } \\
\text { young people }\end{array}$ & 135.54 & 136.09 & 164.49 & 7.02 & 0.030 \\
\hline Having childcare (home economy) services & 136.70 & 134.50 & 165.57 & 7.74 & 0.021 \\
\hline Increasing / improving educational opportunities & 149.24 & 135.65 & 152.66 & 2.70 & 0.259 \\
\hline $\begin{array}{l}\text { Improving infrastructure facilities (road, } \\
\text { communication, etc.) }\end{array}$ & 148.13 & 137.84 & 150.07 & 1.51 & 0.470 \\
\hline Increasing non-agricultural job opportunities & 133.98 & 142.65 & 151.93 & 2.07 & 0.356 \\
\hline $\begin{array}{l}\text { Providing support against natural disasters (flood, } \\
\text { hail, frost, etc.) }\end{array}$ & 141.46 & 138.83 & 154.31 & 2.00 & 0.368 \\
\hline $\begin{array}{l}\text { Providing additional job opportunities for family } \\
\text { members }\end{array}$ & 143.41 & 140.56 & 144.97 & 0.17 & 0.920 \\
\hline Guaranteed product prices & 144.16 & 143.82 & 144.12 & 0.00 & 0.999 \\
\hline Increasing credit opportunities & 132.07 & 141.05 & 165.12 & 7.38 & 0.025 \\
\hline Increase in the number of agricultural cooperatives & 134.29 & 144.13 & 157.04 & 3.27 & 0.195 \\
\hline Training on marketing etc. & 133.65 & 139.82 & 163.34 & 6.14 & 0.046 \\
\hline $\begin{array}{l}\text { Developing to produce agricultural products with } \\
\text { contracts }\end{array}$ & 135.78 & 142.27 & 158.62 & 3.46 & 0.177 \\
\hline $\begin{array}{l}\text { Having information about product prices before } \\
\text { producing }\end{array}$ & 139.70 & 143.78 & 147.38 & 0.39 & 0.823 \\
\hline Availability / increase of storage services & 139.29 & 145.36 & 149.03 & 0.63 & 0.730 \\
\hline Having transportation services & 141.92 & 143.49 & 149.30 & 0.38 & 0.827 \\
\hline Information on packaging & 137.22 & 141.99 & 157.45 & 2.76 & 0.251 \\
\hline The convenience of packaging supply. etc. & 140.11 & 140.94 & 155.96 & 2.02 & 0.364 \\
\hline
\end{tabular}

Source: Survey results, 2019.

factors more important than others did. They wouldn't like to lose money because of unpredictable product prices and have additional jobs their children against if something goes wrong in production phases. Prices of products can be guaranteed by the government, which has provided so far for some strategic products.

\subsubsection{Impact of ageing on agricultural activ-} ities 
Figure 2 - Decisions taken because of ageing (\%).

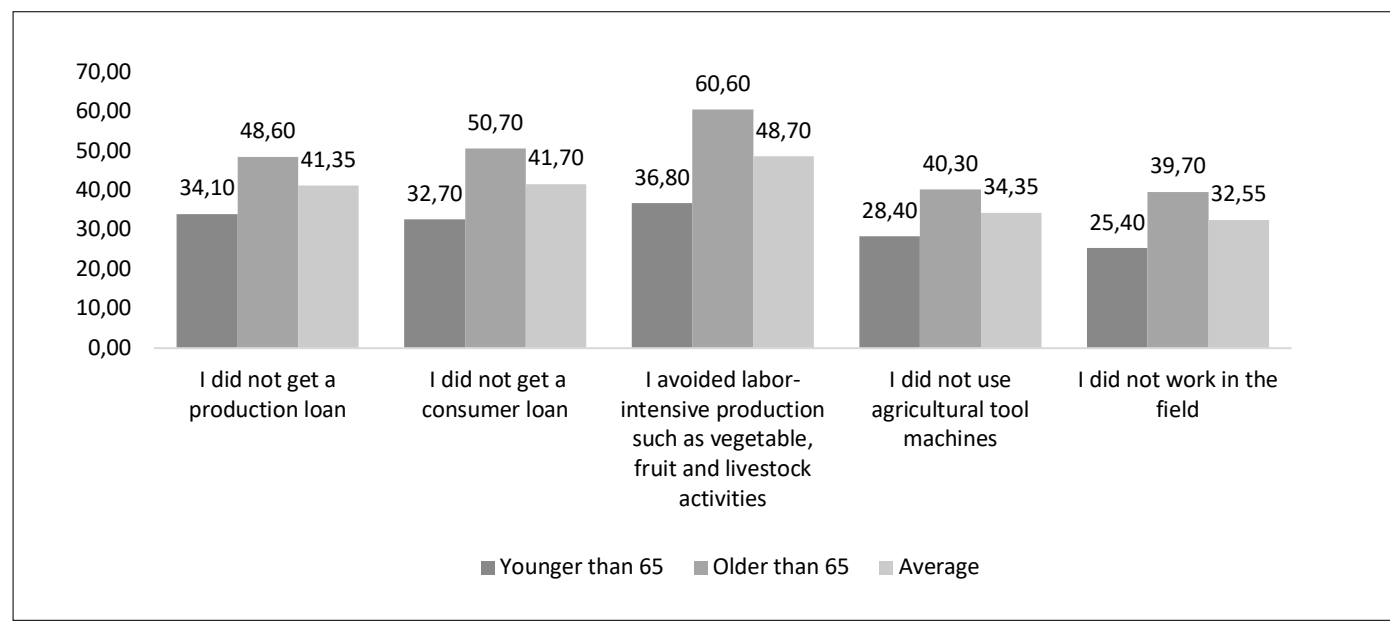

Source: Survey results, 2019.

Producers see ageing as a state marked by a physical or physiological change, several experiences acquired, sometimes being accompanied by health problems, loneliness due to the departure of children, or the loss of loved ones, all of this reminding them of the approximation to death. Because of their advanced age, $50 \%$ of the farmers say they have difficulties in carrying out activities such as administrative formalities (registration in the register of farmers, insurance, etc.) and in the use of new technologies. Regarding operations, the impact of ageing can be seen through the disinvestment of $57.7 \%$ of the farms surveyed. The farm manager, seeing his advanced age, refrains from making considerable investments such as the acquisition of new equipment or tractors ( $60 \%$ of farms that are disinvesting). Among the group of farmers that are disinvesting, the sale of land capital $(5.6 \%)$, and the sale of their tractor (s) $(12.2 \%)$ are other decisions taken over the past 10 years due to ageing. The results from the cross-tabulations analysis are shown in Figure 2.

This analysis shows that compared to younger producers, $23.8 \%$ of older producers refrain (more than the latter) from undertaking profitable new crops.

However, the idea of expansion in the event of youth or resumption of activity by the children heirs, whether through the renewal of equipment $(90.3 \%)$, diversification towards more profitable speculations (91.8\%) such as breeding (90.4\%), or even the installation of an irrigation system $(77.8 \%)$, is fully approved by most producers regardless of age; the idea of using credit was much less prominent $(52.4 \%)$.

Another impact of age on decisions is the limitation of credit. According to our result, ageing also impacted the loan demand of farmers. Famers above 65 avoid taking consumption loans $18 \%$ and production loan $14.5 \%$ times more than the youngers.

In addition to the reduction in the level of agricultural activities mainly by older producers, there is the sale of land capital and the reduction in the number of producers. The participants of our survey affirm that in the space of 10 years the number of farmers in the areas of our study has fallen by $23.71 \%$ and by $26.26 \%$ for that of large farms. $6 \%$ of the producers surveyed reveal that they have personally sold agricultural land over the past 10 years (on average 10 decares per person) and $75.1 \%$ of the respondents state that during this same period, agricultural land was sold. Among the reasons for the sale, the willingness of the heirs not to continue the activities weighs $15 \%$, the move of the owner outside the village contributes $16 \%$.

In many cases, these lands were acquired by people outside the village, with the objective of agricultural production $(36.6 \%)$, an investment or to live in the countryside $(28.8 \%)$. 
In addition to the disinvestment of farms by the sale of land capital or work equipment, there are unexploited lands according to $50.7 \%$ of participants in our survey. On average per village, $54.6 \%$ of unexploited land covers 101 to 400 decares and $25.9 \%$ more than 400 decares. The causes identified are mainly conflicts of division between heirs $(38.8 \%)$, insufficient income from the farm $(23.0 \%)$, and the advanced age of the farm manager $(15.1 \%)$.

\section{Discussion}

Our study works on the sustainability issue in the ageing rural population context. Starting with the implication of farmers' family members in the activity, the results show that at most $30 \%$ of the decisions are made in concert with family (wife and children); the implication of the family in the decisions is more around future, marketing planning than production activity. Errington (1998) in his study claims that when there is a successor, the delegation of tasks and decisions starts first with technical decisions, farm planning operations; then come to the managerial and strategic planning decisions, and lastly the financial decisions.

Our study reveals that $45.6 \%$ of the farmers do not expect a succession by their children whereas Lobley et al. (2010) in their study about farm succession and retirement found a rate below $35 \%$ for United States farmers that could identify a successor. In comparison with England that has a succession rate lightly above $50 \%$, the authors established a link between the age of the farmer and the likelihood of having a successor for England and Canada. The reasons evocated are mostly the attractiveness of the other sectors (Figure 1). Off-farm income being higher and stable, children of older farmers are more likely to exit agriculture for the off-labour market (Corsi and Salvioni, 2017). Besides the insufficiency of the income of farmers, the amount of subsidies is considered as not enough to encourage the production. In their study, Mili et al. (2017) demonstrate the role of subsidies through simulation; when subsidies are well addressed, there will be more conversions of olive farms to more environment friendly systems in Andalusia. These assessments and opinions gathered corroborate with the phenomenon of the rural exodus that occurs during the transition of the economy of the countries. In their study about the farm succession process, Uchiyama et al. (2008) noticed that the farm size play an important role in the decision of heirs to take up the succession. They explain it by the fact that larger farms present more opportunities for the older and younger generation to work together whereas heirs from smaller farms prefer to be employed off the farm.

The phenomenon of transition in the economy which can be noticed by the reduction in the percentage contribution of the agricultural sector to GDP (in favour of the tertiary sector), manifests itself in the agricultural sector through mechanization and, to a certain extent, through its industrialization whose origins date back to post-war 1939, when scientific progress was used to ensure the food for populations mostly devastated by war (FAO, 1955). This explains why $65.8 \%$ of producers strongly agree with the fact that agricultural activities are easier than before, just as much as agronomic knowledge is more accurate (64.4\%).

Focusing on the consequences of ageing on productivity, results reveal that $50 \%$ of our survey participants declaring not being able to do administrative formalities. When analyzing the issue in Thailand and Japan, Poungchompu et al. (2012) discovered that despite their will, old farmers tend to be less productive thence leading to the risk of food insecurity when the phenomenon is coupled with labour force reduction. Guo et al. (2015) came to a similar conclusion in their study where $58.53 \%$ of Chinese agricultural producers are likely to quit farming representing a threat to the active population if the succession does not take place.

Going on with the productivity perspective, the disinvestment rate of farms in our study is alarming (57.7\% are concerned). The decision of disinvestment and turning to static management can be explained by the lack of successor just as have noticed Inwood and Sharp (2012) in their study. Calus et al. (2008) in their work reveal that farms with designated successors may do more investments. Still, to assess the impact of age on the decision-making of farmers, they 
were asked what actions or initiatives they have not taken due to the age factor.

Like it can be guessed, the age factor made $60.60 \%$ of older farmers $(23.8 \%$ more than the less old ones) avoiding some new crops (Figure 2 ). One of the reasons is the amount of labour involved in these farming activities. In his study of the ageing of the rural population in India and its implication for agriculture, Milovanović (2018) came out with a similar result that farmers younger than 60 work twice harder and more intense than their older counterparts.

The sale of land capital and the reduction of the producer population are self-explanatory. In his study about the rural exodus, Akdemir (1994) came up with the result that during the migration, families disinvest their farm to start a new life and invest in the city. Lobley et al. (2010) in their comparative study noticed that a great percentage of Canadian farmers (Ontario and Quebec) plan to sell land and other farm assets to fund retirement. The more farmers have enough income amount plan from private sources or government allocation, the less they plan to sell land or farm assets.

One information conveyed by $23 \%$ of sales of agricultural land to pay off debts is that agricultural producers, instead of resorting to consumer credit, prefer to sell their goods.

While analyzing a similar problem in China, it was found that the decision of leaving farmland idle is related to the absence of a successor (Sottomayor et al., 2011; Lin and Wang, 2014).

The impact of ageing on productivity continues with the credit aspect also. The study helped to notice that ageing impacts the consumption of loans of farmers. That finding appears to be compatible with the one of Stiglbauer and Weiss (2000) who found that when a successor is designated, the farms increase their borrowing capacity to invest in farming. Considering these results, and also the fact that age affects the use of agricultural equipment (11.9\% more than the others) and also on the accomplishment of agricultural work (14.3\%), it appears that the ageing of the rural agricultural population has a significant impact on production capacities in general, through production factors.

To sum up, the study, following previous studies, reveals that ageing impacts the farmers by their attitude of disinvestment, reduction of loan consumption, reduction of production capacity, avoidance of some new activities, and so forth that will inevitably be reflected on the performance, the innovation and competitiveness of the sector. The impact of the ageing continues to the level of the rural development in the way that, there is a capital transfer from rural areas to cities, whenever farms are disinvested due to the lack of successors or to finance the rural exodus of family members in the seek of the better farm off opportunities. Moreover, agriculture being one of the major economic activities in rural zone, rural exodus, capital transfer, and abandonment of farming also mean loss of added value and possible regression of economy in those parts of the country; which is clearly not an advantage for development in rural regions.

Tackling the threat that is planning on the sector, requests policies that will make agricultural sector and rural areas a hub of opportunities. Succeeding into making rural environments attractive (with necessary infrastructures, development projects), instead of rural exodus may lead to interest from the rural population or even urban population. One of those policies can be to develop agro-polis in or around respective production areas based on their core product(s). Developing the (or a big part of the) value chain in a rural area may solve the problem of migration and hence the one succession and farm disinvestment.

Proposing solutions requests to take into account the causes of the situation or at least the essential ones. One of the issues making agriculture less attractive for farmers and their heirs is the profitability of the agricultural activities. Indeed, in a changing economic environment with the inflation phenomenon, farmers are the ones bearing the biggest part of the augmentation of the cost of inputs' prices, as commodities' prices on the market barely change in response to the inflation. Whenever it changes, the biggest share goes to the other parts of the chain such as retailers of agro-food companies. In other words, the ageing population and its impacts on agricultural sustainability should be taken as a consequence (and not a cause) of all the difficulties that gangrene the production link of the agricultural chain, to be able, first to 
diagnose those difficulties and then design tailored solutions or policies. As an example of a solution from farmers themselves, cooperative association, when well executed, turns out to be a potential solution for land consolidation, increasing farmers' power in the chain, solving the problem of succession, and thus, the one of disinvestment of farms. By the same token, converging individual strengths through cooperative or any form of association is an opportunity to reach the economy of scale, an excellent asset in this more and more competitive world.

\section{Conclusion}

In a context where the Turkish population is experiencing a phenomenon of rural exodus, mainly juvenile, following the transformation of its economy, study and understand the structural changes and the economic situation of the agricultural sector that employs more than $18 \%$ of the population and contributes to $5.8 \%$ of the national GDP is a necessity. The ageing of the rural and especially agricultural population has the effect of abstaining from agricultural activities among layers of older producers, both in terms of the diversification of productions, the renewal of production assets as well as investments or even acquisition of credits. Because the latter represent about a quarter of the agricultural population in our study, added to the fact that $45.6 \%$ of respondents doubted the succession of the agricultural holding, it is understood that the question of the sustainability of family farms and, by extension, that of the agricultural system is threatened. The research has also provided insight into how farmers think and make decisions and what kind of activities they do not like to do when they get older. The results are relevant for the formulation of social programs taking into account older producers, as they inform about the main turning points in the life of farmers and highlight the agricultural activities, which should be progressively more or less encouraged according to the age of the farmers.

As a result, for the sustainability of agriculture, it is imperative to solve structural problems related to land and business and to provide an environment that will ensure socio-econom- ic prosperity. In addition to providing access to land for producers with little land (leasing, sharecropping, and land acquisition), consolidation of fragmented and scattered lands, the opening of dry agricultural lands to irrigation, widespread use of productivity-enhancing technologies can be a good start. Ensuring agriculture-industry integration, diversifying and increasing non-agricultural income sources, marketing, and taking a series of measures on value chain issues will increase the attractiveness of the countryside and contribute to the sustainability of agriculture. As a result:

- Strengthening the institutional capacities of young agricultural entrepreneurs in terms of competition, use of production technologies, mechanization, marketing, and value chain, (becoming a part of an organization and digital marketing).

- It is important to support young entrepreneurs more in Rural Development investments, to expand the projects and activities related to alternative non-agricultural income sources, and to encourage the entrepreneurship of youth in rural areas.

- About consolidating land, it is important to transfer shares to actual users by using land banking practices, to scale up and to support productivity-enhancing investments in growing lands.

\section{Acknowledgement}

This paper is elaborated as a part of the project "Aged Population in Agricultural and Rural Development" (project ID: FBA-2019-12036) that has been supported by the BAP institution of Çukurova University.

\section{References}

Acici G.Ç., 2019. Old Age in Rural Areas: Problems, Expectations and Solutions Recommendations. Master's Thesis, Akdeniz University Institute of Social Sciences Department of Sociology, Antalya, Turkey [Turkish].

Akdemir S., 1994. The effects of rural exodus from the GAP region on capital transfer. Cukurova Uni- 
versity Journal of Agricultural Faculty, 10 (1): 131146 [French].

Akdemir S., Miassi Y., 2019. Ageing of the rural population and its impact on world agricultural production. In: $11^{\text {th }}$ International Congress of Social Sciences with Current Research, pp. 429-434.

Altin C., 2014. Seasonal migration and poverty: Case of Ankara-Polatl seasonal agricultural workers. Master's Thesis, Süleyman Demirel University, Institute of Social Sciences, Department of Sociology, Isparta, Turkey [Turkish].

Andel J., 2003. Statistické metódy (Statistical methods). Prague: MATFYZPRESS [Slovak].

Avsar Z.G., 1995. Migration from rural to urban areas in Turkey and imbalance among regions (19701993). Ph.D. Thesis, Mimar Sinan Fine Arts University, Institute of Social Sciences, Department of Sociology, Department of Institutional Sociology, İstanbul, Turkey [Turkish].

Calus M., Van Huylenbroeck G., Van Lierde D., 2008. The relationship between farm succession and farm assets on Belgian farms. Sociologia Ruralis, 48: 38-56.

Corsi A., Salvioni C., 2017. Once part-timer always part-timer? Causes for persistence in off farm work state of farmers. Bio-based and Applied Economics, 6: 159-182.

Coskun O., Zaman S., 2012. An applied study about urban adaptation of rural population migrating to cities and their urbanization level: Erzurum example. International Journal of Human Sciences, 9(1): 1050-1062 [Turkish].

Ekmekciler U.S., 2011. Economic and social effects of rural migration: Example of the province of Diyarbakır. Ph.D. Thesis, Istanbul University Institute of Social Sciences, Department of Economics, İstanbul, Turkey [Turkish].

Errington A.J., 1998. The intergenerational transfer of managerial control in the farm-family business: A comparative study in England, France and Canada. Journal of Agricultural Education and Extension, 5: 123-136.

Eswaran H., Reich P.F., Beinroth F.H., 1997. Global distribution of soils with acidity. In: Moniz et al. (eds.), Plant-soil interactions at low pH: Sustainable agriculture and forestry production. Proceedings of the $4^{\text {th }}$ International Symposium on PlantSoil Interactions at Low pH, 17-24 March 1996, Belo Horizonte, Brazil, pp. 159-164.

Etikan I., Musa S.A., Alkassim R.S., 2016. Comparison of Convenience Sampling and Purposive Sampling. American Journal of Theoretical and Applied Statistics, 5(1): 1-4.
FAO, 1955. La situation mondiale de l'alimentation et de l'agriculture - 1955. Rome: FAO.

Griffin B., Hartarska V., Nadolnyak D., 2019. Retirement age farmers' exit and disinvestment from farming. International Journal of Economics and Finance, 11(12): 136-148.

Guo G., Wen Q., Zhu J., 2015. The impact of ageing agricultural labour population on farmland output: from the perspective of farmer preferences. Mathematical Problems in Engineering, 2015: 730618. Availableathttp://dx.doi.org/10.1155/2015/730618.

Gurbuz M., Karabulut M., 2008. An Analysis of Relationships between Rural Migration and Socio-Economic Properties. Turkish Geographical Journal, 50: 37-60.

Hettmansperger T. P., Möttönen J. and Oja H., 1998. Affine invariant multivariate rank tests for several samples. Statistica Sinica, 8(3): 785-800.

Inwood S.M., Sharp J.S., 2012. Farm persistence and adaptation at the rural-urban interface: succession and farm adjustment. Journal of Rural Studies, 28: 107-117.

Kuçuk S., 2018. Ageing Population and Social Policy: the World and Turkey Applications. Master's Thesis, Karadeniz Technical University, Institute of Social Sciences, Department of Labor Economics and Industrial Relations, Trabzon, Turkey [Turkish].

Lin H., Wang H., 2014. Problems of family farms in China and countermeasures. Asian Agricultural Research, 6(6): 1-4.

Lobley M., Baker J.R., Whitehead I., 2010. Farm succession and retirement: Some international comparisons. Journal of Agriculture, Food Systems, and Community Development, 1(1): 46-64.

Mili S., Judez L., De Andres R., 2017. Investigating the impacts of EU CAP reform 2014-20 and developments in sustainable olive farming systems. New Medit, 16(3): 2-10.

Milovanović V., 2018. Population ageing in rural India: implications for agriculture and smallholder farmers. Ph.D. thesis, Czech University of Life Sciences Prague.

Mollavelioglu S., Mihci H., Cagatay S., Ulucan A., 2010. Assessment of sustainability of the European Union and Turkish Agricultural sectors. New Medit, 9(3): 13-21.

Palinkas L.A., Horwitz S.M., Green C.A. et al., 2015. Purposeful Sampling for Qualitative Data Collection and Analysis in Mixed Method Implementation Research. Administration and Policy in Mental Health and Mental Health Services Research, 42: 533-544. https://doi.org/10.1007/s10488-013-0528-y. 
Poungchompu S., Tsuneo K., Poungchompu P., 2012. Aspects of the Aging Farming Population and Food Security in Agriculture for Thailand and Japan. IJERD - International Journal of Environmental and Rural Development, 3(1): 102-107.

Reboul C., 1980. Inflation et choix des techniques agricoles 1970-1979. Économie rurale, 140: 21-29.

Shucksmith M., 2010. How to promote the role of the youth in rural areas of Europe? Directorate General For Internal Policies Policy Department B: Structural And Cohesion Policies Agriculture And Rural Development. Brussels, European Parliament. http://www.europarl.europa.eu/studies.

Sottomayor M., Tranter R., Costa L., 2011. Likelihood of succession and farmers' attitudes towards their future behaviour: evidence from a survey in Germany, the United Kingdom and Portugal. The International Journal of Sociology of Agriculture and Food, 18(2): 121-133.

Stiglbauer A.M., Weiss C. R., 2000. Family and non-family succession in the Upper-Austrian farm sector. Cahiers d'Economie et de Sociologie Rurales, 54: 5-26.

Tasgin G., 2009. A Study on Rural Development Potential in Oltu District of Erzurum Province and the Migration Problem. Master's Thesis, Ataturk University Graduate School of Natural and Applied Sciences Department of Agricultural Economics, Erzurum, Turkey [Turkish].

TOB (Ministry of Agriculture and Forestry of the Republic of Turkey), 2019. 13 billion increase of revenue is targeted by the advantage of unused agricul- tural lands to agriculture [Turkish]. Accessed on January 08, 2021, at: https://www.tarimorman.gov. tr/Haber/1707/Atil-Tarim-Arazilerinin-Tarima-Kazandirilmasi-Ile-Yillik-13-Milyar-Liralik-Gelir-Artisi-Hedefleniyor.

TurkStat, 2019. Population migrating between provinces by age group and gender. Accessed on September 21, 2019, at http://www.tuik.gov.tr/PreIstatistikTablo.do?istab_id=2621.

TurkStat, 2020. Elderly Statistics 2019. Accessed on January 08, 2021 at: https://data.tuik.gov.tr/Bulten/ Index?p=Istatistiklerle-Yaslilar-2019-33712\#: :tex$\mathrm{t}=\mathrm{TÜIK} \% 20$ Kurumsal\&text $=$ Yaşl1 $\% 20$ nüfus $\% 20$ olarak $\% 20$ kabul\%20edilen, $9 \% 2 \mathrm{C} 1 \% 27 \mathrm{e} \% 20$ yükseldi [Turkish].

Uchiyama T., Lobley M. Errington A., Yanagimura S., 2008. Dimensions of intergenerational farm business transfers in Canada, England, the USA and Japan, Japanese Journal of Rural Economics, 10: 33-48.

Voss D.T., 2010. Testing is confidence estimation: Partition multiple testing. Journal of Statistical Theory and Practice, 4(4): 559-569. doi:10.1080/ 15598608.2010.10412004.

Wilcox R.R., 2009. Nonparametric estimation. In: Belsley D.A, Kontoghiorghes E.J. (eds.), Handbook of Computational Econometrics. Chichester: John Wiley \& Sons Ltd, pp. 153-182. https://doi. org/10.1002/9780470748916.ch5.

Yalcin G.E., Kara F.Ö., 2016. Rural Migration and Effects on Agricultural Production. Harran Journal of Agricultural and Food Sciences, 20(2): 154-158. 